\title{
Interjecția în texte vechi românești
}

\author{
Margareta Manu Magda* \\ Institutul de Lingvistică „Iorgu Iordan - Al. Rosetti”, Calea 13 Septembrie 13, 050711 București, România
}

\begin{abstract}
Despre articol
Istoric:

Primit 1 iunie 2017

Acceptat 6 iulie 2017

Publicat 30 septembrie 2017

Cuvinte-cheie:

interjecție

expansiune diacronică

derivare semantică

româna veche

româna modernă

pragmatizare

Rezumat

Lucrarea încearcă să identifice problemele speciale puse de studiul interjecției în limba română veche (pe baza examinării unui corpus de texte aparținînd perioadei 1600-1780, raportate la texte din româna modernă). Am urmărit în ce mod anumite formațiuni interjecționale au dobîndit, prin expansiune diacronică, noi valori gramaticale, semantice și pragmatice.

Structura lucrării este următoarea: secțiunea introductivă $(\$ 1)$ prezintă pe scurt poziția autoarei privind statutul ocupat de categoria interjecției la nivel morfosintactic, semantic și pragmatic ( $\$ 1.1)$ și privind relaţia dintre diverse structuri lingvistice și procesul lor de gramaticalizare / pragmatizare ( $\$ 1.2)$; $\$ 2$ se referă la traseele specifice urmate de evoluția diverselor categorii de interjecții analizate, de la româna veche spre româna modernă: prezentativele adecă, iată, $n i(\$ 2.1)$, hortativele haide, $n i(\$ 2.2)$, conativele bre, măi $(\$ 2.3)$, conectorii cu funcție de semnale demarcative adevăr, amin ( $\$ 2.4) ; \$ 3$ are ca obiectiv descrierea unei specii de derivație delocutivă, ilustrată, în limba română, de variantele semantice lexicalizate ale interjecției secundare Doamne!; studiul se încheie cu cîteva concluzii referitoare la rezultatele cercetării $(\$ 4)$.
\end{abstract}

\section{Preliminarii}

1.1. Autorii care s-au ocupat în ultimii ani de studiul interjecției sînt de comun acord cu faptul că aceasta are o importantă funcție în comunicare și că semnificațiile și funcțiile ei diferă de la o limbă la alta ${ }^{1}$.

Astfel, limba română dispune de un inventar extins de formațiuni interjecționale, înregistrat și descris în lucrări de profil. Pentru româna modernă, dispunem de o bogată bibliografie a problemei ${ }^{2}$. Pentru româna veche, descrierea construcțiilor interjecționale acoperă o bibliografie mai restrînsă ${ }^{3}$.

1.2. În studiul de față, vom urmări traseele specifice parcurse de anumite interjecții cu valori prototipice din româna veche în evoluția lor spre româna modernă. Am selecționat pentru analiză cîteva dintre cele mai reprezentative formațiuni interjecționale din categoria prezentativelor (adec $\breve{a}$, iată și ni ), a hortativelor (haide și ni), a adresativelor (bre, măi), a conectorilor cu funcție de semnale demarcative (adevăr, amin), și a emotivelor (interjecția secundară Doamne!). Vom încerca să prezentăm în ce mod unele dintre aceste elemente lexicale, în condițiile anumitor constrîngeri morfosintactice și pragmatice contextuale, își modifică în timp forma, sensul și/sau funcția (unele interjecții se gramaticalizează / pragmatizează, consolidîndu-și noul statut: „grammatical material become more grammatical”, Traugott, 1995, p. 15).

1.3. Am utilizat, ca bază teoretică, în stabilirea statutului lingvistic al interjecției, modele propuse în literatura de specialitate a ultimilor ani: a) modelul explicativ (cognitiv) al procesului de "subiectivare” („subjectification” - vezi Traugott, 1989 și 1995²) și b) modelul semantico-pragmatic specific evoluției interjecțiilor (vezi, între altele, Gonçalves, 2000 și 2002; Hopper \& Traugott, 1993).

\footnotetext{
*Adresă de corespondență: margaretamagda@yahoo.com.

${ }^{1}$ Vezi, în acest sens, „Journal of Pragmatics”, vol. 18, nr. 2-3, 1992, consacrat integral studiului interjecției [online].

${ }^{2}$ Pentru prezentarea inventarului și tipologiei interjecțiilor din limba română standard, cf., între altele, GALR, I, Interjecția, p. 657-686 și GALR, II, Grupul interjecțional, p. 119-123.

${ }^{3}$ Frâncu (2009, p. 151-154; p. 335-336) prezintă un inventar al principalelor interjecții din limba română veche.

${ }^{4}$ În Traugott (1995, p. 46), „subiectivarea” („subjectification”) este definită ca dezvoltare a unei expresii gramaticale în legătură cu atitudinea sau credința vorbitorului referitoare la ceea ce spune.
} 
Margareta Manu Magda

1.3.1. Aspecte definitorii ale interjecției. Categoria lingvistică a interjecției, avînd ca trăsături definitorii intonația exclamativă și non-flexiunea, este o clasă de cuvinte eterogenă, atît sub aspect gramatical, cît și sub aspect semantic.

a) Sub aspect gramatical, interjecția este o subcategorie diferențiată de alte subcategorii ${ }^{5}$ deoarece:

- este o frază non-prototipică (un echivalent al frazei care, asemenea fragmentelor sintagmatice de tip pro-frază, nu prezintă structura subiect - predicat $)^{6}$;

- este o subcategorie ale cărei elemente, numite de unii cercetători ${ }^{7}$ semnale lingvistice, sînt mărci ale unui act de predicație non-frastic.

b) Sub aspect semantic, interjecția este caracterizată printr-o semnificație vagăă, fapt ce permite utilizarea ei într-un număr foarte mare de contexte care îi influențează sensul prototipic. Aceste semnificații contextuale, fixate în timp, se convenționalizează.

c) Sub aspect pragmatic, categoria interjecției prezintă o anumită omogenitate, avind în vedere baza de definiție de natură performativă și capacitatea interjecției de a evolua în direcția altor categorii funcționale. La acest nivel, interjecția interacționează cu formațiuni precum exclamația, vocativul și imperativul, în performarea unor acte lingvistice ca avertizarea, injuria, insulta, jurămîntul sau blestemul etc.

1.3.2. Premise ale derivării semantice. În teoria gramaticalizării, schimbarea semantică este redată printrun număr de termeni precum: bleaching, desemanticisation, semantic loss și weakening; numitorul comun al sensului acestor termeni este de „pierdere” (loss). În cazul tipic de gramaticalizare, avem a face cu o redistribuire sau o alunecare de sens, nu cu o pierdere (Hopper \& Traugott, 1993, p. 84). „Alunecarea” este un proces gradat, prin care forme și construcții, la început exprimînd sensuri lexicale primare, concrete și obiective, prin utilizare repetată, în contexte sintactice locale, ajung să îndeplinească funcții tot mai abstracte, pragmatice, interpersonale, bazate pe reacția vorbitorului (la Traugott, 1995, p. 32, „subjectification").

\section{Direcții de evoluție a unor interjecții din româna veche spre româna modernă}

În sec. al XVI-lea și în prima jumătate a sec. al XVII-lea, inventarul de interjecții cuprindea numeroase elemente moștenite sau împrumutate care, ulterior, au dispărut sau și-au restrîns utilizarea.

Textele românești vechi evidențiază o mare instabilitate funcțională a semnalelor lingvistice interjective. Acestea prezintă o evoluție frecvent recognoscibilă în diacronie (prin forme coexistente în sincronie). Datorită echivalenței semantice dintre unele interjecții și diverse părți de vorbire (verbe, pronume, adjective sau adverbe), interjecțiile sau grupurile interjecționale, construite în jurul interjecției, pot ocupa poziții sintactice specifice respectivelor clase de cuvinte ${ }^{8}$.

\subsection{Prezentativele adică, iată, ni}

Interjecția prezentativă este principalul mijloc gramaticalizat pentru realizarea operației de prezentare în limba românăg. În secolul al XVI-lea, interjecțiile prezentative prototipice sînt adecă și iată, forme

\footnotetext{
${ }^{5}$ După autori precum Cuenca (1997), Cuenca \& Hilferty (1999), Gonçalves (2000) etc.

${ }^{6}$ Cf. Gonçalves (2000, p. 4): „tous les équivalents de la phrase qui ne présentent pas de structure sujet-prédicat, comme les fragments syntagmatiques, les pro-phrases, etc. sont donc des phrases non prototypiques. Les interjections constituent alors une sous-catégorie de la catégorie grammaticale de niveau basique fragment”.

${ }^{7}$ Cf. Olivier (1985), care clasifică semnalele lingvistice în „signaux linguistiques anonymes, formules interpersonnelles stéréotypées et interjections".

${ }^{8}$ „Între clasa interjecției și celelalte clase de cuvinte există treceri în ambele sensuri: cuvinte aparținînd altor clase devin interjecții secundare, pierzîndu-şi total sau parțial sensul de bază şi dezvoltînd valori afective, expresive, iar interjecțiile pot constitui baze de derivare pentru verbe și substantive, în general (accidental, și pentru adjective), prin sufixare, respectiv articulare, atașarea unor desinențe substantivale sau adjectivale ori a unor determinanți substantivali (ca procedee mai frecvente).” (Croitor, în GALR, I, p. 677).

${ }^{9}$ Prezentativele prototipice, pentru clasa în discuție, sînt iată (iacă, iacătă, ia(n)) și uite (uitați) și variantele populare ale acestora: ete, iete, iote, oite, uiche, uie, ute, încadrabile în categoria interjecțiilor conative, ,care contribuie la a lua cunoștință”, de
} 
concurente care se dezvoltă divergent. Prima s-a specializat, în timp, cu valoare de marcă prototipică a reformulării, pierzînd funcția prezentativă, după ce o vreme cele două sensuri ale acesteia au coexistat la nivelul textelor ${ }^{10}$. Regional, sînt înregistrate și îni, iani, iane și $n i^{11}$ „iată”. Unele dintre aceste forme sînt polisemantice, putînd folosi la exprimarea unor modalități de prezentare variate. Aceeaşi marcă de prezentare poate corespunde unui spectru de funcții diferite în raport cu tipul de construcție sau de context.

Dăm mai jos cîteva variante ale prezentativelor citate, ilustrative pentru alunecarea de sens, și, în final, pentru modificarea de statut gramatical, despre care vorbeam.

2.1.1. ADIC $\breve{A}^{12}$ (cu variantele adecă și adăcă), ,iată”, „uite”

(adverb $\rightarrow$ interjecție $\rightarrow$ conector de reformulare)

Avînd valoare primară de adverb, folosirea interjecțională a lui adică este deosebit de frecventă în textele din epoca cercetată: „adică este în plină concurență cu iată (iacă)” (Frâncu, 2009, p. 151). Au fost identificate în texte următoarele utilizări: sens prezentativ propriu-zis (prezentativ al existenței și al identității) (1); valoare de întărire, parafare a celor prezentate într-un act administrativ (2a,b); sens (element) citațional (3); sens explicativ (alunecare spre valoarea conectivului de reformulare) (4a-c).

(1) Patriarşii încep cîntare: Adecă, Dumnezeul nostru înălță-se. $\left(\mathrm{CC}^{2} .1581,194\right)$

(2) a. Adecă eu, Marin o(t) Boldești, scris-am acest zapis [a]l meu [...] cum să se știe că am vîndut ocina din Scrovişte. (Dî, VII, Zapis de vînzare, Dîmbovița sau Prahova, 1582)

b. Adecă eu, Iorga, feciorul buscăi de Bunești, scri<u> eu și mărtu<risesc >. (Dî,, CIV, Zapis de cumpărare, Bunești - j. Vaslui, [1595-1597])

(3) Că zice svînta scriptură: Blaže(n) mu(ž), adecă „Ferice de bărbatul ce nu mearge spre sfatul necuraților și pre calea păcătoşilor”. (Dî, LIX, Însemnare, Galați, 1570-1571)

(4) a. Dupăcuvîntul ce grăise, că „mainainte”, zice, „de cemă verichema, zic: Adecă, eu” (cc².1581, 20)

b. Ce adecă, aceastea toate să le părăsim și să meargem după Hristos. $\left(\mathrm{CC}^{2} .1581,75\right)$

c. Ce se zice limbile, adecă cum ai zice, impreună tot omul ce-i smeri păcatului. ( Cc $^{2} .1581$, 558)

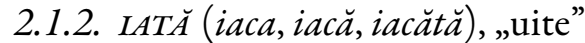

(valoare demonstrativă $\rightarrow$ interjecție prezentativă $\rightarrow$ valoare argumentativă / conector)

Utilizată inițial cu sens „demonstrativ” (avînd ca scop de a atrage atenția alocutorului asupra prezenței efective și singularizante a unui obiect din lumea referențială, dirijîndu-i privirea asupra acestuia din urmă), interjecția iată a pătruns în română din bulgară $(<\text { eto, ete etc. })^{13}$, cel mai probabil prin intermediul textelor

către alocutor, de o „ofertă” (intenție) a locutorului. Pentru inventarul prezentativelor în limba română, cf. DA, DEX, MDA s.v.

${ }^{10}$ „Presentatives are predicates with an NP / DP or a clausal complement, or parenthetical markers. Parenthetical presentatives may be pragmaticalized as focalizers or discourse connectors. In the $16^{\text {th }}$ century (see Manu Magda, 2014), adecă and iată are in competition, since they have very similar functions; adecă is the only presentative marker in $\mathrm{CP}^{1} .1577$ and Ps.1573-8 and it is the most frequent one in PH.1500-10, Св.1559-60, CV.1563-83, while iată is preferred in СТ.1560-1, $\mathrm{CC}^{1} .1567, \mathrm{CC}^{2} .1581$; in PO, the form iaca prevails (Zafiu, 2015a). In the second OR period, adecă (which is less integrated into the syntactic structure from the earliest texts) loses its presentative function (except for some legal formulas) and becomes a prototypical paraphrastic reformulation marker (Zafiu, 2015a; Zamfir, 2015; \$4.8.2). In MR, iată preserves all its functions, while adding new pragmatic values; iaca and iacătă also continue to be presentatives, but they are restricted to the colloquial register" (Zafiu, în SOR, p. 602).

${ }^{11}$ Cf. N. Drăganu, Prefață la CTd.1600-40, p. 150: „Haşdeu (Cuv. II, p. 112 și 235) vedea în formele îni și iani pe latinul en (cf. gr. v., pol. ano, anu, nordsrb. ano, slav. na, ung. ne, ni, germ. nu, na, cari toate sînt înrudite în privința fonetică și a înțelesului). Astăzi se aude în, ian sau zani și ni. Ini ar putea corespunde latinescului en, ni e unguresc, iar iani și iane e mult mai probabil că sînt compuse din $i a$ («Wohl nicht lat. eja, sondern alb., bulg. ia», Tiktin-Rum.-Deutsches Wb., p. 746) cu ungurescul ni, ne. - ia+ni, ia+ne (cf. și Tiktin, ibid., p. 748)”. Vezi și Frâncu (2009, p. 154).

${ }^{12}$,Cuvînt de origine controversată (după DA, de origine necunoscută, după Philippide, Principii de istoria limbii, p. 7, din id est quort sau ad id quod, ultima etimologie e preluată și de Scriban (DLR), după Procopovici, Dacor. X, 79 din adest eccum, după Ciorănescu din lat. adxque „deopotrivă, la fel”)" (apud Frâncu, 2009, p. 151).

${ }^{13}$ IATĂ! Interj. 1. Voilà; Voiçi, 2. Voilà que (soudain) [...] Din bulg. Jato, idem (eto, ete etc. Eto če ... „iată că”); (DA, s.v.). 
Margareta Manu Magda

bisericești, în texte românești scrise de diverse facturi, urmînd inițial tiparul de utilizare preluat din textul slavon și dezvoltînd ulterior alte sensuri contextuale.

Concomitent cu forma cultă, interjecția iată a pătruns și prin filieră populară (dialectală), în variante ca ete/iete etc., în graiurile sudice (oltenești, muntenești), concurînd forma locală uite și dînd naștere unor forme contaminate cu aceasta din urmă $(5 \mathrm{a}, \mathrm{b})$ :

(5) a. Am treierat și cu caii, ete aici chiar aveam aria (TDO, 335)

b. Bre, tataie, iote-așa, iote-așa, și noi avem un berbec! (TDM II, 498)

În mod tradițional, iată s-a specializat pentru realizarea prezentării textuale (scrise) ${ }^{14}$. În textele consultate, realizează toate valorile fundamentale specifice prezentativelor: sens prezentativ propriu-zis (prezentativ al existenței și al identității) (6a-d); valoare de întărire, parafare a celor prezentate într-un act administrativ (7); valoare argumentativă (8).

(6) a. Şi iată acestu om al mieu ce am tremes la domniia-voastră, el este frate acelui fecior. (Dî,, Scrisoare, Transilvania, 1599-1600)

b. Zise Rabila: "Iaca, aicea Bala, slujnica mea”. (po.1582, cap. 30, 3)

c. Iosif, iară, zise: „Iaca, unde sănt”. ( ( 0.1582 , cap. 37, 14)

d. Iaca, domnu-mieu cu aceaea unde eu sănt la el, pre nemică grije nu purtă. (po.1582, cap. $30,39)$

(7) Iată eu egumenul și tot săborul de la mănăstirea de la Muldoviță. (Dî, LXXXII, Scrisoare, Suceava, Mănăstirea Modovița, [30 iunie 1592])

(8) Şi neavînd cine o lega, iată jiupîneasa Tămăşoaie grecoaia să află [de] o deade la meșter de o legăă, ca să aibă și ea pomeană. (Dî, LIX, Însemnare, Galați, 1570-1571)

\subsubsection{Formațiuni în expansiune}

Interjecțiile prezentative (ca și cele injonctive - vezi mai jos) tind, în timp, să preia poziția gramaticală a verbului $^{15}(9,10)$, fapt întărit și de prezența, în context, a unui complementizator - aici, $c \breve{a}(9 \mathrm{a}-\mathrm{c}, 10)$.

(9) a. Iaca că am început a grăi cu Domnul (po.1582, 59)

b. Care lucru iată că și fu (ICP 1700, 88v)

c. Ce, cumu-m zise, eu și făcui, și iacătă că văz! (Po.1582, 185)

d. Iată-ți muiarea ta (PO.1582, 45)

e. Iacătă-l undeșade (A.1620, 11 ${ }^{\mathrm{r}}$ )

(10) Oprită fu bunătatea de pre pămînt dentr-acealea zile de ce fusease zis: „Adecă, că se voru lăsa casele voastre pustii". ( $\left.\mathrm{CC}^{2} .1581,211\right)$

În secolul al XVI-lea, cele două prezentative discutate coexistă uneori în același context $(11 \mathrm{a}, \mathrm{b})$ (Densusianu, 1961, II, p. 161, apud Zafiu, în SOR, p. 604); „adecă ocupă primul loc (echivalînd cu un conector) și iată, poziția secundă (funcționînd ca focalizator)" (Zafiu, în SOR, p. 604).

$$
\text { a. Demîneața iară, adecă iaca Liia (PO.1582, 98) }
$$

\footnotetext{
${ }^{14}$ Iată se referă la existența relativă a unei ființe, care poate fi abordată într-o manieră particularizată sau nu. Valoarea semantică forte, la care ne referim, justifică utilizarea foarte frecventă a acestui prezentativ în texte religioase (unde necesitatea confirmării, cu absolută certitudine, a existenței divine și a lucrărilor acesteia este obligatorie). Iată și-a extins apoi, treptat, funcționalitatea în textele beletristice. În comunicarea orală colocvială, această interjecție lipsește aproape cu desăvîrșire. Retorica bazată pe utilizarea în număr mare a prezentativelor textuale în argumentație se regăsește, pe alocuri, în discursurile oficiale actuale și, recent, este foarte productivă în comunicarea din presa vorbită. Referitor la comportamentul prezentativelor în româna modernă, vezi Manu Magda (2009a).

${ }^{15}$ „Pot avea funcție de predicat, admițînd unele dintre complinirile verbului (complement direct, exprimat prin substantiv, pronume, inclusiv prin clitice, sau propozițional, dativ posesiv, predicativ suplimentar)” (Croitor, în GALR, I, p. 674).
} 
b. Adecă, iată, carei se delungă de tine, pier. $\left(\mathrm{Cc}^{2} .1581,15\right)$

În evoluția lor spre româna modernă, prezentativele dezvoltă valori pragmatice de conectori precum: conector narativ, marcînd discontinuitatea sau surpriza (12a), în special, după construcții temporale sau condiționale (Avram, 1960, p. 47, apud Zafiu, în sor, p. 604), conector conclusiv (12b) etc.

(12) a. Ce cugetînd el aceastea, iată îngerul Domnului și să arătă lui. (NT.1648, $3^{\mathrm{v}}$ )

b. Căzu adecă soțul lui, la picioarele lui (NT.1648, 24 ${ }^{\mathrm{r}}$ )

\subsection{Interjecțiile hortative}

Interjecțiile hortative au un parcurs diacronic mai complex decît prezentativele, în evoluția lor de la și înspre alte clase lexico-gramaticale.

\subsubsection{BLEM (bleți, blemați), PAS( $\breve{A}), V \breve{A}$}

(forme verbale $\rightarrow$ interjecții $\rightarrow$ dispar în româna modernă)

În epoca românei timpurii, caracterizată prin rigiditate mai mare a modelelor retorice utilizate în redactare, precum și prin prezența scăzută a elementelor oralității, specifice dialogului, textele consultate conțin interjecții, provenite din forme verbale de imperativ cu sens directiv, precum blem, bleți, blemați ${ }^{16}(13 \mathrm{a}, \mathrm{b})$, $\operatorname{pas}(\breve{a})^{17}(14 a-d)$ și $v \breve{a}^{18}(15 \mathrm{a}-\mathrm{e})$, izolate în româna tîrzie și înlocuite cu alte forme, de factură interjecțională (elementul colocvial de origine turcă hai(de) și elementul de sorginte maghiară $n i^{19}$, cu variantele iane / iani) (v. infra, \$2.3.2).

(13) a. Dzisă: „Blem, frate Ciacal, [...]” (CD.1698, 70)

b. Blăm de-m arată. (A.1620,72)

(14) a. Pasă, pasă, Alexandre, că ție nu e dat să lăcuiești tu cu noi. (A.1620, 32)

b. Filoane, pasă dară și-i zi să iasă Alexandru. (A.1620, 5)

c. Pasă lăuntru la faraon și dzi aceasta lui (Po.1582, cap. 8, 1)

d. S,i pasă inaintea lui pre țărmurile apeei. (PO.1582, cap. 7, 15)

(15) a. Dzise fata lui faraon ei: „Vă!” (po.1582, cap. 2, 8)

b. Vă, derept aceaea, și adună într-una bărbații lu Izdrail. (po.1582, cap. 3,16)

c. Zise Ietro lui: „Vă cu pace!” (Po.1582, cap. 4, 18)

d. "Vă înaintea lu Moisi în pustie!” (Po.1582, cap. 4, 27)

e. Vă la faraon, măne demăneață. (PO.1582, cap. 7, 15)

\subsubsection{NI, LANE (iani)}

2.2.2.1. Interjecția $n i$ cu sens hortativ, după un imperativ sau conjunctiv (16a-e), identificată atît în textele nordice, cît și în cele sudice din secolul al XVI-lea, își restrînge circulația spre nord, fiind astăzi atestată cu valoare prezentativă doar în limbajul regional $(17,18)$.

\section{ROMÂNA VECHE}

(16) a. Ni, să dzidim o cetate și turnul cui vărvul să agiungă la ceriu. (po.1582, cap. 11,4)

b. Ni, săpogorîm gios şi să turburăm limba lor. (Po.1582, cap. 11,7)

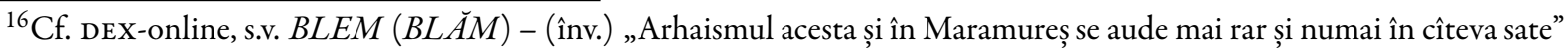
(Țiplea, 1906, p. 432). - Lat. ambulo, ambulare („a umbla”) > imbla (re) > umbla. Alături de cuv. formate în rom. cu pref. în(îm-) utilizate cu și fără prefix: bătrîni / îmbătrîni, tineri / întineri, sănătoși / însănătoși, bucur / îmbucura etc., și aici s-a utilizat forma fără îm-, considerîndu-se că e prefix și nu un cuvînt moștenit (Felecan, 1994, p. 38).

${ }^{17}$ Cf. DEX-online, s.v. $P \breve{A} S A^{2}$, pers. 3 pásă.

${ }^{18}$ Cf. DEX-online, s.v. $V \breve{A}$ (lat. vade).

${ }^{19}$ Cf. DEX-online, s.v. NI interj.
} 
c. Derept aceasta, ni, să dăm vin a bea tatălui nostru. (po.1582, cap. 19, 32)

d. Zise Laban: „Ni, batăr, aşa să fie cum dzici”. (po.1582, cap. 30, 34)

e. Ni, deaca amu ai vrut să te duci [...], derept-ce ai furat domnedzeii miei? (po.1582, cap. 31, 30)

\section{ROMÂNA DIALECTALĂ}

$N i$ (< magh. nez) este astăzi o interjecție prezentativă cu circulație regională restrînsă (Transilvania centrală și nord-vestică). Avînd, în general, sensul lui uite, formațiunea funcționează, în primul rînd, cu valoare de intensificare, singură sau în cumul cu alte mărci din aceeași categorie (17a,b). Cel mai frecvent, acest prezentativ este asociat cu deictice ostensive (pronumele, adjectivele și adverbele demonstrative, pronumele personale de persoana a III-a, ca și articolele hotărîte), manifestînd diverse stadii de clișeizare $(18 \mathrm{a}-\mathrm{c})^{20}$.
a. „nii!” zîce „, se lup mare iesă colo pe dos” // „undi-i?” // (TDN, 41)
b. d-apăi uite ni! / primăvara / adică iarna no / le grijîm acasă // (TDN, 85)
a. ciobanu care-i rîndu să dușe cu oile / iestălalt stă... de la stîna / pe rînd așa ni // (TDN, 223)
b. avea cuptoriu / din casă /și un ciubăr așa ni / une merea [...] băga lemnile aşa ni // înc-amu am de-alea ni // (TDN, 224)

2.2.2.2. Regional, sînt înregistrate și iane, iani, „iată” (19). Frâncu (2009, p. 154) consemnează faptul că, asemenea lui ni, iane $($ iani) < ia + ne ,își retrage treptat întrebuințarea după 1600 la unele texte nordice: iane (CV.1563-83, 20v/12; CC $\left.^{2} .1581,315,364,407\right)$, iani (?, XII, 100 $/ 11$, XIV, 113 $/ 5,8$; CTd.1600$\left.40,102^{\mathrm{r}} / 2,16,110^{\mathrm{v}} / 1\right)^{\prime \prime}$.

(19) Iane a-mu trupe (стd.1600-40,110 $)$

\subsection{3. $\operatorname{HAI}(D E)^{21}$}

(interjecție hortativă cu multiple utilizări contextuale $\rightarrow$ valoare de imperativ $\rightarrow$ conector)

În româna veche, o dată cu pătrunderea elementelor specifice oralității colocviale în textele consultate, sînt înregistrate și interjecțiile hortative de origine turcă hai(di/de) (cu circulație largă în Balcani) ${ }^{22}$. Acestea se extind, în timp (în special în varianta vorbită a limbii și mai puțin în româna scrisă, cu excepția stilului presei), și fac carieră în româna modernă colocvială, glisînd spre statutul de verb (prezintă un început de paradigmă desinențială, asemenea lui poftim, uite $)^{23}$.

Prin însăși natura $\mathrm{ei}^{24}$, hai a fost caracterizată drept interjecția tipică a interacțiunii ${ }^{25}$ în limba română. Această formă alocutivă este specializată pentru comunicare în structuri dialogale care presupun, obligatoriu, prezența (reală sau imaginară) a unui alocutor. De aceea, interjecția în discuție pătrunde tîrziu în varianta scrisă a românei, mai cu seamă în texte aparţinînd stilului beletristic. În acest context, ia locul imperativelor blem, pas(ă), ia (ni), conservă valoarea de imperativ cu care adesea se și însoțește (20a), tinzînd să-l înlocuiască $(20 b-d)$ (alăturîndu-se vocativului $-20 c, d)^{26}$.

\section{ROMÂNA VECHE}

\footnotetext{
${ }^{20}$ Pentru acest subiect, vezi Manu Magda (2009b).

${ }^{21}$ Vezi, de exemplu, TDRG, s.v.: „türk. hayde, $-d i$, $-d a$; in allen Nachbar- u. Balkansprachen.

${ }^{22}$ Acestea sînt considerate (v. Frâncu, 2009, p. 335) inovații ale epocii prefanariote și fanariote (1640-1680).

${ }^{23}$ Pentru descrierea statutului acestor interjecții în româna modernă, vezi, între altele, Manu Magda (2009a).

${ }^{24}$ Avînd sens apropiat de al imperativului, interjecțiile hortative prezintă unele trăsături comune cu vocativul și cu imperativul: pot apărea izolat în frază, se rostesc cu o intonație specială și servesc spre a ne adresa cuiva; de aceea interjecțiile acestea pot însoți un vocativ sau un imperativ (GALR, I, p. 667).

${ }^{25}$ Formularea aparține Rodicăi Zafiu (2005).

${ }^{26}$ Contextual, interjecția hai (de) poate fi asociată sau (din ce în ce mai frecvent) asimilată: cu un imperativ (ori o expresie performativă) sau cu conjunctivul hortativ. În utilizarea inițială, termenul hai(de) a fost asociat cu imperativul unor verbe de mișcare („Vino! veniți! să mergem!”). În această configurație, hai(de) manifestă disponibilitățile combinatorii ale verbului substituit. Vezi, în acest sens, DEX online, s.v. Hai.
} 
(20) a. Una dintre dînsele zise cître cealaltă: - Hai să ne coborîm aici. (CPR, 207)

b. Au dzis copilului: „Hai ghidi cahpol!” (NL 1750-66, 222)

c. Hai mare prislestiață ce ești. (CD.1698, 160)

d. Haide, prietine, vino să-ți arăt cîte feluri de bucate facem astăzi (CPR, 235)

\section{ROMÂNA MODERNĂ}

$\mathrm{Cu}$ toate că aparține, prin definiție, unei clase de cuvinte neflexibile, interjecția hai(de), cu valoare de imperativ, prezintă, în româna modernă, un început de flexiune (avind forme cu desinența verbală de persoana a II-a plural -ți: haideți (21a) sau cu desinența verbală de persoana I plural - $m$ : haidem (21bd); aceasta din urmă are o sferă de utilizare mai restrînsă - „popular și învechit”).
a. A: Haideți să-ncercăm. (IVRLA, 193)
b. - Aimée, știi ce? Haidem la Constanța!
- Haidem! rosti ea spontan...
- Atunci haidem in vagonul-restaurant pentru refacere.
- Haidem, Aimée, e timpul să mergem.
(M. Drumeș, Invitație la vals, apud Pană Dindelegan (2009), p. 533-536)
c. Şi-işopti: - Haidem la Sala Catalană.
(M. Eliade, Maitreyi și alte proze, apud Pană Dindelegan (2009), p. 533-536)
d. Vă rog și vă implor să haidem insuportabili stînd și înțelepți...
Haidem să fim rude, i-am spus...
Haidem să ne mișcăm, îmbrățtişarea vieții mele.
(N. Stănescu, Epica Magna, apud Pană Dindelegan (2009), p. 533-536)

În anumite contexte, hai(de) se alătură elementelor limbii care au rolul de a se referi la componentele actului comunicativ, funcționînd ca marcator discursiv. În texte monologate, interjecția hai (de) are calitatea de conector discursiv (în formule clișeizate), marcînd diverse roluri argumentative (dirijînd decodarea intențiilor cu care a fost formulat un enunț $)^{27}$.

\subsection{Interjecțiile adresative $e^{28}$}

\subsection{1. $B R E, M \breve{A I}$}

(interjecție conotată „popular” $\rightarrow$ interjecție conotată „familiar” $\rightarrow$ valoare de vocativ)

\section{ROMÂNA VECHE TÎRZIE}

Interjecțiile adresative și fatice sînt absente din textele vechi; ele apar, sporadic, în primele texte beletristice ale românei tîrzii, pătrunzînd în literatura secolului al XIX-lea și al XX-lea ${ }^{29}$, pentru a domina mai toate contextele românei moderne unde tind să preia, uneori, comportamentul gramatical al vocativului (adesea precedînd un substantiv în vocativ, cu care formează o unitate intonațională sau luîndu-i locul) ${ }^{30}$.

(22) a. Bre, bei, om necunoscătoriu... (CD.1698, 125)

b. Ceți-i voia, măi? (NL 1750-66, 21)

\footnotetext{
${ }^{27}$ Vezi GALR, II, Conectori frastici și transfrastici, \$3.2 și Manu Magda (2009a, p. 482-483).

${ }^{28}$ „Interjecțiile prin care este apelat destinatarul sînt numite adresative sau apelative. În rîndul lor, există o oarecare structurare prin specializarea unor interjecții pentru destinatari cu trăsătura [+uman]: hei, mă, măi, falfă, alo, bă, băi, bre, pst... În multe situații, interjecțiile adresative însoțesc substantive în cazul vocativ, întărind valoarea adresativă a acestora. Dintre interjecțiile cu destinatari [+uman], numai fa/fă este specializată, pentru destinatari de sex feminin, ca urmare a provenienței sale din substantivul fată" (Croitor, în GALR, I, p. 667).

${ }^{29}$ Cf., pentru acest subiect, Chivu et al. (2015).

${ }^{30}$ Vezi Manu Magda, în GALR, II, p. 893-895.
} 
2.3.2. BRE, $M \breve{A I}, M \breve{A}, F \breve{A}, M \breve{A R} E^{31}$ (ultimul termen dispărut din uz)

RoMÂNA DIN SECOLUl AL XIX-LEA

Interjecții adresative mai frecvente, în secolul al XIX-lea ${ }^{32}$, sînt: bre, măi, mă, fă, măre:

(23) a. „Nu vă temeți, măre, lăsați” (N. Filimon)

b. „Fa, fa Ioană (V. Alecsandri)

c. „Of! mări frate” ( $\mathrm{V}$. Alecsandri)

d. "Şi ce-ai să-ifaci, măi Neagu?" (V. Alecsandri)

\section{ROMÂNA MODERNĂ}

În utilizarea acestor termeni de interpelare care exprimă îndemnul la luare de contact între vorbitori și

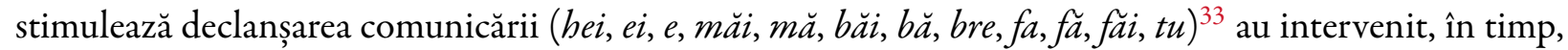
modificări structurale și funcționale. Termenii, în discuție, sînt folosiți, cu precădere, în registrele nonstandard (regional, popular). Excepție fac mă!, măi!', prezente în comunicarea familiară chiar și a unor categorii de vorbitori educați (de pildă în limbajul presei vorbite). În acest sens, se remarcă o tendință de slăbire în intensitate a valorii de utilizare a formulelor de politețe și de întărire a valorii apelativelor interjecționale $m \breve{a}, b \breve{a}, b \breve{a} i, b r e, t u$.

(24) a. Măi Mărine, te mai pui cioban la vară? Mă pui, bă nea Ioane. (TDo, 997)

b. Mă, nu știu dacă ți-e de folos ce ți-am spus eu. (IVLRA: 42)

c. - Vrei să mă conduci acuma pă mine pă la spate... Băi, dumneata vrei să-ți spui ceva? (?, 2004).

- Caragiale avea o vorbă: „Ce să caute neamțu' in Bulgaria?” "Ce caută, bă, românu' in Irak, băi?!" „Ce cauți, bă, la noi, bă? Cin'te-a trimis?” (?, 2003).

d. A: Măi! Eu spun o chestie foarte serioasă! Dă bine, mă!

B: Stați, bă!... (?, 2003).

\subsection{Interjecții cu valoare de conectori transfrastici}

2.4.1. $\operatorname{ADEVĂR}(A T)$ (lat. ad + de + verum) $)^{34}$ și $A M I N^{35}$ (sl. aminü < gr. amin, ebr. amen)

Interjecțiile pot avea diverse valori comunicative (consemnate mai sus) sau pot funcționa drept conectori pragmatici. Cu această ultimă funcție, unele sînt specializate pentru anumite contexte: amin, bogdaproste, aleluia și osana aparțin limbajului religios ritualizat; altele sînt folosite, de exemplu, ca semnale demarcative, în texte administrative (scrisori, documente oficiale, legi), care impun o exprimare concisă, lipsită de ambiguitate. În esență, aceste semnale pun în valoare instrucțiunile conținute în textul la care sînt anexate. (Vezi cazul interjecțiilor arhaice, izolate, cu aspect clișeizat ${ }^{36}$ adevăr $(25 a-c)$ și amin (26a-c). Prima dintre ele a ieșit din uz, a doua este utilizată astăzi numai în limbajul bisericesc.)

\section{Documente}

\footnotetext{
${ }^{31}$ MẮRE interj. 1) (se folosește pentru a exprima mirare, nedumerire, curiozitate). 2) (folosit și ca termen de adresare) Măi. [Var. mări] / cf. alb. more, ngr. moré (NODEX, 2002, s.v.).

${ }^{32}$ Apud Croitor, în Chivu et al. (2015, p. 276-281).

${ }^{33}$ Cf. Manu Magda, în GALR, II, p. 893-895.

${ }^{34}$ Cf. DEX-online, s.v. adevărát ${ }^{2},-\breve{a}$.

${ }^{35}$ Există o serie de interjecții (propriu-zise) împrumutate din alte limbi. Unele împrumuturi au fost făcute în limba veche (aleluia, amin, osana din limba slavă, bogdaproste din limba bulgară, bre din limba turcă, haide din limbile turcă, bulgară și neogreacă etc.), altele în perioada modernă și contemporană (Croitor, în GALR, 2008, I, \$5.1). În DEX-online, s.v. AMÍN interj. 1) (se folosește ca formulă de încheiere în textele religioase, în rugăciuni etc.) Adevărat; aşa să fie. 2) fam. S-a terminat!; adio! /<sl. aminu, sursa: ? (2002).

${ }^{36}$ „Tendința limbilor naturale este de a clișeiza sensurile procedurale de succes și de a forma colocații cvasistabile din sintagme inițial libere” (Ștefănescu, 2007, p. 215).
} 
(25) a. Adevăr, făcut-am tocmeală, ce Domneata ai trimes credincios<ul> măriii tale de credință [...] (Dî, XXXI, Scrisoare, Transilvania,1600)

b. Şi să fiț Dumiile-voastre sănătos, adevăr. (Dî, XCVII, Scrisoare, Suceava, [1593-1597])

c. Păntru aceaea dăm știre domiitale și să te veselești de la Dumnedzău, adevăru. (Dî, CX, Scrisoare, Suceava, [1600])

(26) a. Dumnezeu pre mijloc de noi. Amin. (Dî, XVI, Zapis de vînzare, J. Prahova, 1597-1600)

b. De-această vă dămu în știre și Dumnezeu să vă ție sănătoși și întru pace bună, amin. (Dî̀, XVIII, Tîrgoviște, [1599])

c. Dumnezeu lungească zilele domitale, amin. (Dî, XCIII, Scrisoare, [1593])

\section{LITERATURĂ RELIGIOASĂ VECHE}
a. ... și acmu și purure și în veci adevăru. (?, 69 ${ }^{\mathrm{r}}$ )
b. Așteptămu scularé morților. di vecie vecului. adevăru. (?, 121 $\left.{ }^{\mathrm{v}}\right)$
c. Că aceasta amu, adevăr, bună iaste și cu folos și spăsenie. $\left(\mathrm{CC}^{2} .1581,25\right)$
a. iarî direpții | intru părîțiia ceriului. $\mid$ amin $\left(?, 106^{\mathrm{v}}\right)$
b. Că a lui e slava și ținearea, intru nesfirșiții veacii veacilor, amin. $\left(\mathrm{CC}^{2} .1581,107\right)$

\section{Interjecții emotive: cazul interjecției secundare Doamne!}

\subsection{Interjecții secundare}

În mod curent, în lingvistică se face deosebirea între interjecții primare, care au întotdeauna utilizare interjecțională, și interjecții secundare ${ }^{37}$, care au utilizare interjecțională în virtutea semnificației lor (Ameka, 1992, p. 105).

Interjecțiile secundare se încadrează toate în subclasa interjecțiilor propriu-zise și au o funcție comunicativă emotivă. Acestea provin, în general, din substantive ${ }^{38}$ și, într-o măsură mai mică, din verbe, adverbe, pronume și sintagme nominale. Subclasa interjecțiilor secundare mai înregistrează grupuri prepoziționale şi propoziții împietrite.

\subsection{Premise ale derivării semantice}

3.2.1. În continuare, vom ilustra, pe scurt, comportamentul interjecției secundare prototipice Doamne! ( Dumnezeule!) în textele vechi românești consultate, raportat la cel din texte de română modernă ${ }^{39}$.

Doamne! ( Dumnezeule!) aparține clasei de formule interjecționale care includ, la nivel sincronic, mai multe etape ale unei cronologii derivaționale. Vom prezenta, pe scurt, etapele derivării delocutive a termenului, pornind de la utilizarea formei nominale a apelativului într-o situație de rugăciune (considerată context situațional discursiv implicit), la cea interjecțională, clișeizată, a acestuia. Această situație este creată de către un locutor care pune în scenă, împreună cu un alocutor, prin și pentru discurs, un act de limbaj implicit (cu dublă semnificație - „implorare” și, totodată, „elogiere”), adecvat situației respective. Derivarea delocutivă, de la forma nominală la cea interjecțională a termenului, se bazează, tocmai pe această dublă semnificație a actului de limbaj sugerat implicit de context.

\footnotetext{
37 „Interjecțiile secundare sau improprii sînt create pe terenul limbii române din alte părți de vorbire sau din diverse sintagme ori propoziții care, în urma unei întrebuințări frecvente și prin accentuarea valorii afective, au căpătat statut de interjecții. Cînd sînt folosite cu valoare interjecțională, aceste cuvinte sau grupuri de cuvinte își pierd, total sau parțial, sensul lexical propriu, căpătînd nuanțe afective suplimentare și își schimbă comportamentul gramatical, fiind invariabile din punct de vedere morfologic și independente sintactic” (vezi Croitor, în GALR, I, Interjecţia, \$5.1).

38 „Substantivele care se pot converti în interjecții secundare se grupează în cîteva clase semantice: nume de rudenie (mamă, măiculiță, tată, frate, soră), substantive din sfera religioasă (Dumnezeu, Domn, drac, naiba, păcat), termeni de adresare frecvent folosiți (domn, nene), rar nume proprii” (Croitor, în GALR, I, Interjecția, \$5.1.1).

${ }^{39}$ În acest sens, vezi lucrarea noastră, Manu Magda (2017).
} 
Margareta Manu Magda

3.2.2. Forma de bază pentru derivarea semantică a cuvîntului, în procesul de glisare spre valoarea de interjecție secundară, este cea nominală, alocutivă, cu funcția de formulă de apel adresată divinității, în cursul rugăciunii. Domn (< DŎM $(\breve{I})$ NUS, nominativ) este utilizat, cu această funcție, în special cu desinență de vocativ, Doamne (< DŎMĬNE): - ca termen de adresare către divinitate $(29 \mathrm{a}-\mathrm{d})$; - ca termen generic de adresare către „stăpîn, domnitor” (30a-b); - ca termen generic comun de adresare politicoasă către un bărbat, domnule (vocativ articulat) / pl. domnilor (30c).

a. Doamne, spăseaşte-ne! $\left(\mathrm{CC}^{2} .1581,109\right)$

b. Milosîrd ești tu, Doamne! ( cc $\left.^{2} .1581,65 / 67\right)$

c. Domnul den ceriu, iartă-ne noi. (CLRV.1559, 66)

d. Dumnezeu, cu urechile noastre auzim. (CLRV.1570,96)

(30) a. Doamne impărate (FD.1592-604, 168)

b. Zise: "Rogu-te, Doamne, <s>ă am aflat mila înaintea ochilor tăi, nu încungiura sluga ta" (Po.1582, cap. 18, 3)

c. Domnilor și boierilor (CLM.1700-50, 293)

\subsection{Stadii ale derivării}

În continuare, vom pleca de la ipoteza (enunțată de Olivier, 2000, p. 161 și urm.) că formațiunile interjective, identificate în diverse contexte, nu reprezintă manifestări de polisemie ale acestui termen, ci realizări lexicalizate, în plan diacronic, ale unui continuum semantic ${ }^{40}$. Acest continuum conține mai multe stadii:

3.3.1. Stadiul de bază (situația primitivă) al procesului derivațional conține formula Doamne!, cu funcție nominală, ca suport pentru toate celelalte stadii. Potențialul expresiv al formulei (31) derivă din aceea că sensul termenului beneficiază de păstrarea, în memoria vorbitorului, a conținutului prototipic de rugăciune, conservat, implicit, în formula de apel.

(31) Aceasta grăiia, că de acmu zis ifu „Doamne, spăseaște-ne!” ( CC $\left.^{2} .1581,109\right)$

3.3.2. Primul stadiu interjecțional al expresiei se caracterizează printr-o slăbire a situației prototipice de „rugăciune” (prin ambiguizarea identității alocutorului), și conservarea exclusivă a valorii de „situație excepțională” din sfera semantică a acesteia.

\section{ROMÂNA VECHE}

Textele de română veche marchează acest stadiu prin utilizarea (și perfecționarea procedeului în faza tîrzie a perioadei studiate) a unor tehnici retorice convenționalizate (între care exclamația adresată deține un rol privilegiat, v. 33a-c). În triunghiul conversaţional locutor - alocutor - martor, locutorul (prin elemente discursive) organizează și regizează discuția, asigură o atmosferă favorabilă comunicării, prefigurînd un dialog cu un potențial receptor $(32 a-d)$, căruia îi revine un rol activ în crearea semnificațiilor. „Grație expunerii adresate, destinatarul încetează a fi o entitate abstractă, virtuală, devenind parte integrantă a unei construcții dialogale, în care i se atribuie rolul de confident, dar și de coparticipant la formarea textului” (Cvasnîi Cătănescu, 2006, p. 75).

a. Ceși David amu răpștind arătă-se: „Pînă cînd păcătoșii, Doamne, pînă cînd păcătoșii laudăse?" $\left(\mathrm{CC}^{2} .1581,2\right)$

b. Şidzise Avraam: // „Doamne Domnezeu, dence voiu cunoaște că voi birui acesta?” (Po.1582, cap. 15,8$)$

\footnotetext{
${ }^{40}$ Cf., în acest sens, Olivier (2000): „...nous ferons l'hypothèse d'un continuum sémantique reliant ces différents emplois. Selon nous, on ne peut conclure à une véritable polysémie : chaque emploi porte la trace des types d'emplois qui le précèdent dans l'ordre dérivationnel... chaque emploi porte la trace des types d'emplois qui le précèdent dans l'ordre dérivationnel. La classe des formules interjectives laisse voir dans un même état de langue plusieurs étapes d'une chronologie dérivationnelle” (p. 161).
} 
c. Că pre adevărat, Doamne, au călcat împărații Asiriei limbile și păgînii. (?, 71)

d. „Ce este omul, Doamne, de-ai făcut pentru el atîta mărire?” (?,294)

a. Doamne, Domnul nostru, cît iaste de minunat numele tău [...]! (?, 29)

b. O, cît sîntu de infricoşate lucrurile tale, Doamne! (?, 63)

c. O, Doamne, impăratul mieu, atîta dragoste și pateme ai pus pentru noi. (?, 160)

$\mathrm{Cu}$ toate că nu am identificat, în textele vechi, stadiul interjecțional final, am atestat, la cronicari, două exemple marcînd faza de pragmatizare foarte avansată, prezentă și astăzi în româna vorbită:

(34) Intr-una de dzile, cu meșterșug i-au împărțit, pre unii la o samă de agii curții sale, la ospățu, văz doamne, pre alții la alți agi și la masa sa... (CLM.1700-50, 227 $7^{\mathrm{r}}$ zac 19)

(35) Scris-au veziriul cu scîrbă la pașa de Tighine, dzicînd că beiul de Moldova este un ghiaur și știe toate ce să facu la Moscu și la Ieși, de le scrie tot adevărat la Poartă „iar tu ești, vedzi doamne, busurman sinus,tii nemic!” (NL 1750-66, 196)

3.3.3. În stadiul interjecțional final, toate utilizările derivate ale termenului Doamne! conservă, din situația primitivă, emoția sugerată de exclamație și de gestul interjectiv. În acest ultim stadiu al derivării delocutive, termenul, în discuție, atinge un nivel avansat de pragmatizare, dobîndind funcția prototipică de intensificare. Comunicarea își pierde substratul primitiv sacru și trece într-o situație de comunicare profană. Doamne! interjectiv se apropie de valoarea interjecțiilor $A h !, O h !$, cu care se și însoțește, și care marchează gradul înalt de emotivitate, dar pornind de la o situație primitivă diferită - cea a strigătului $(\text { vezi } 36 a, b)^{41}$.

\section{ROMÂNA MODERNĂ}

În româna modernă, „Doamne!” a dobîndit valoare interjecțională datorită conţinutului său afectiv special, desemnînd numele divinității supreme. „Doamne!” pierde rolul de adresare sau de chemare, ca în situațiile cînd este folosit cu sensul propriu, fiind utilizat în exprimarea unei reacții emotive, cu valoare interjecțională.

În calitate de interjecție secundară, „Doamne!” realizează enunțuri (nestructurate) independente sintactic, prefaţînd sau încheind alte enunțuri pe care le completează afectiv. Diferența față de varianta substantivală este reflectată de intonație ${ }^{42}$.

(36) a. Ob, Doamne, nu poți să-ți imaginezi! O să las o parte din mine, aici, in capitală! (online)

b. Şi vine chelnerița, vede în ziar poza din tinerețe a actorului și zice, topită de emoție: „Vai, Doamne, cît era de frumos!" (online)

În mod prototipic, aceste enunțuri se asociază cu sintaxa exclamativă ${ }^{43}$. Generate de formațiunea în discuție, exclamațiile nominale însoțesc, cel mai adesea, construcții exclamative (de tip „wh”) ${ }^{44}$ conținînd tipare sintactice caracterizate prin prezența elementelor exclamative de gradare și de intensificare ale adjectivului sau ale adverbului ${ }^{45}$. Respectivele enunțuri includ, în primele poziții din șirurile sintagmatice prin care se realizează, elemente exclamative de tipul:

- pronumele (adjectivul) ce (37a), urmat uneori de adverbul mai (37b), de prepoziția de (37c) sau de amîndouă:

\footnotetext{
${ }^{41}$ „Si l'on arrive au même type d'effet avec $M D$, unité obtenue par dérivation à partir d'une expression à contenu descriptif, qu'avec un cri parlé, c'est bien que la situation primitive de $M D$ se prête à une telle évolution, même si celle-ci n'a rien d'automatique" (Olivier, 2000, p. 172).

${ }^{42}$ „Caracterul de enunțuri esențial exclamative al interjecțiilor este, în general, marcat în plan suprasegmental” (GALR, II, p. 969).

${ }^{43}$ Cf., în acest sens, Vișan (2002, p. 415-424).

${ }^{44}$ Cf. Vișan (2002, p. 416). Autoarea face deosebire între exclamații, enunțuri cu o anumită forță ilocuționară expresivă, și construcții exclamative, propoziții putînd fi definite, ca atare, în funcție de trăsăturile lor semantico-sintactice.

${ }^{45}$ Vezi GALR, I, Interjecția, $\$ 4.1$. și II, Enunțul, \$4.2.
} 
(37) a. Doamne, ce a apărut în Scornicești! E o statuie tare ciudată. (online)

b. Doamne, ce mai viață! (online)

c. Doamne, ce de bani! 400.000.000 de euro „mişcă" finala Champions ... (online)

- adjectivul pronominal cît (singur sau urmat de prepoziţia de):

(38) Doamne, cît de mult o iubește! (online)

- unde, cum, unde nu (însoțite, în anumite construcții, de adverbul mai, situat la distanță față de conjuncție):

(39) Doamne, cum a putut să iasă Miron Cozma din casă! (online)

Funcția de intensificare (focalizare, gradare, modalizare) a interjecției are două componente (una explicită şi una implicită):

- adresarea directă, realizată prin apel la alocutivul „Doamne!” (numele divinății supreme), conținută în exclamația nominală;

- implicarea unui martor de maxim prestigiu în aprecierea, conținută în construcția exclamativă, care succedă exclamației nominale și vehicularea implicită a unui act lingvistic de prezentare (uite!).

Funcțiile comunicative ale termenului sînt o expresie a gradului de angajare a locutorului în actul comunicativ exprimat prin construcția exclamativă pe care, de regulă, o prefațează.

\section{Consideraţii finale}

În paginile precedente, am semnalat unele aspecte ale variabilităţii semantice dezvoltate, în plan diacronic, de cîteva dintre cele mai semnificative interjecții alocutive ale românei.

Lucrarea de față a evidențiat faptul anumite texte din secolul al XVI-lea dețin un număr mare de forme prin care se realizează categoria semantico-pragmatică a prezentării. Aceste forme sînt adaptate la specificul comunicării de tip juridic și administrativ pe care o practică. Au fost identificate, de asemenea, în literatura religioasă, interjecțiile prezentative livrești, caracteristice limbii scrise (adecă, iată).

Interjecțiile hortative și adresativele, specifice limbii vorbite, au o pondere comunicativă mai redusă în româna veche; ele se regăsesc în limba scrisă din epoca prefanariotă și fanariotă.

În textele analizate, am înregistrat forme care și-au modificat statutul funcțional (semantic și gramatical), evoluînd în mai multe direcții:

- de la clasa verbului spre clasa interjecției sau invers (prezentativele, hortativele);

- de la clasa interjecției spre clasa numelui (conativele);

- dinspre diverse alte clase morfologice spre clasa interjecției (interjecții secundare).

Prin utilizare repetată, cu anumite valori, în contexte identice, unele formațiuni tind să se pragmatizeze, devenind mărci de comunicare.

Formațiunile investigate asigură continuitatea funcțională, păstrînd în româna modernă unele dintre valorile deja înregistrate în limba veche (consemnate în dicționare și identificate în texte aparținînd perioadei premoderne), la care s-au adăugat altele noi. Astfel, am consemnat în româna modernă următoarele ${ }^{46}$ :

- interjecția prezentativă textuală iată pătrunde în comunicarea orală ,„semiformală”, preluînd atribuțiile prezentativului uite (în calitate de marcă a cunoașterii perceptuale);

- colocvialul uite, inexistent în româna timpurie, în contexte informale și semiformale, cumulează mai multe valori - manifestînd diverse grade de deplasare către altă funcție decît cea prototipică (contribuie la structurarea discursului, marcînd începutul unei replici în dialog sau o secvență de citare/enumerare ori evidențiază anumite roluri argumentative);

\footnotetext{
${ }^{46}$ Pentru tratarea acestui subiect, cf., între altele, lucrarea noastră, Manu Magda (2009a).
} 
- interjecțiile hortative ocupă astăzi un loc important între elementele care au funcția de mobilizare și demobilizare verbală: hai(de) este interjecția prototipică a acțiunii lingvistice.

Formaţiunile lingvistice de tipul interjecției secundare Doamne! analizate aparțin categoriei alocutivelor pragmatizate, fiind deosebit de frecvente în uzul românei actuale. Acestea funcționază ca mărci comunicative (de intensificare, focalizare, gradare) în contexte tot mai largi de utilizare ${ }^{47}$.

\section{Bibliografie}

\section{A. Corpus}

A.1620 = Alexandria, în Zgraon, Fl. (ed.), Cele mai vechi cărți populare în literatura română, vol. 11, Fundația Națională pentru Știință și Artă, București, 2006.

$\mathrm{CC}^{2} .1581$ = Coresi, Cartea cu învățătură, ed. S. Pușcariu \& Al. Procopovici, Atelierele Grafice Socec, București, 1914.

CD.1698 = Dimitrie Cantemir, Divanul, în Opere complete, I, Divanul, ed. V. Cândea, București, Editura Academiei, 1974, p. $103-405$.

CLM.1700-50 = Miron Costin, Letopisețul Țărîi Moldovei. Opere, ed. P.P. Panaitescu, Editura de Stat pentru Literatură și Artă, București, 1958.

CLRV = Mareș, Al. (coord.) (2016). Crestomația limbii române vechi, vol. I (1521-1639), Editura Academiei Române, București.

$\mathrm{CPR}=$ Cărți Populare Românești, Editura Litera Internaţional, București - Chișinău, [f.a.]

crd.1600-40 = Codicele Todorescu, în Drăganu, N. (ed.), Două manuscripte vechi. Codicele Todorescu şi Codicele Marțian, p. 191-229.

cs.1609-18 = Codex Sturdzanus, ed. Gh. Chivu, Editura Academiei Române, București, 1993.

cv.1563-83 = Codicele Voronețean, ed. M. Costinescu, Editura Academiei Române, București, 1981.

Dî = Chivu, Gh., Georgescu, M., Ioniță, M., Mareș, Al. \& Roman-Moraru, Al. (eds) (1979). Documente și însemnări românești din secolul al XVI-lea, Editura Academiei, București.

FD.1592-604 = Floarea darurilor, în Roman Moraru, Al. (ed.) (1996). Cele mai vechi cărți populare in literatura română, 1 , Editura Minerva, București, p. 119-182.

ICP 1700 = Ioan Cantacuzino, Patru apologii pentru religia creştină ş Patru orații, traduse în limba română la mijlocul secolului al XVII-lea de Nicolae Spătarul (Milescu), ed. E. Dima, Editura Universității „Alexandru Ioan Cuza”, Iași, 2010, p. 3-127.

IVRLA = Ionescu-Ruxăndoiu, L. (coord.) (2002). Interacțiunea verbală in limba română actuală. Corpus (selectiv). Schiţă de tipologie, Editura Universităţii din Bucureşti, Bucureşti.

NL 1750-66 = Ion Neculce, Letopisețul, în Ion Neculce, Letopisețul Țării Moldovei și O samă de cuvinte, ed. I. Iordan, Editura de Stat pentru Literatură și Artă, București, ed. a II-a, 1959.

NT.1648 = Simion Ștefan (ed.), Noul Testament (Bälgrad/Alba Iulia), Editura Reîntregirea, Alba Iulia, 1998.

po.1582 = Palia de la Orăștie, ed. V. Pamfil, Editura Academiei, București, 1968.

TDM II = Texte dialectale, Muntenia. II, publicate sub redacția lui B. Cazacu, de P. Lăzărescu, M. Marin, B. Marinescu, V. Neagoe, R. Pană şi M. Vulpe, Bucureşti, 1975.

TDN = Texte dialectale și glosar, Bistrița-Năsăud, publicate de M. Marin și M. Tiugan, Consiliul Culturii şi Educației Socialiste, Bucureşti, 1987.

TDO = Texte dialectale, Oltenia, publicate sub redacția lui B. Cazacu, de C. Cohuț, G. Ghiculete, M. Mărdărescu, V. Şuteu şi M. Vulpe, Editura Academiei, Bucureşti, 1967.

\section{B. Referințe}

Ameka, F. (1992). Interjections: The universal yet neglected part of speech, în „Journal of Pragmatics", vol. 18, nr. 2-3, p. 101-118, Crossref.

Avram, M. (1997). Gramatica pentru toți, Editura Humanitas, București, p. 291-295.

Chivu et al. (eds) (2015). Studii de istorie a limbii române: Morfosintaxa limbii literare în secolele al XIX-lea și al XX-lea, Editura Academiei Române, București.

Cuenca, M.J. (1997). Defining the indefinable? Interjections (abstract), Fifth International Cognitive Linguistics Conference, Vrij Universiteit, Amsterdam, 14-19 iul.

Cuenca, M.J. \& Hilferty, J. (1999). Introducción a la linguística cognitiva, Editorial Ariel, Barcelona.

Cvasnîi Cătănescu, M. (2006). Retorică publicistică. De la paratext la text, Editura Universității din București, București.

DA = Academia Română, Dicționarul limbii române, serie veche (literele A-B, C, F-I, D-De, J, L-Lojniță), coordonator Sextil Pușcariu, Socec \& comp. și C. Sfetea, București, 1913-1949.

\footnotetext{
${ }^{47}$ Structuri asemănătoare prezintă interjecțiile secundare de tipul „Mamă!” (v. Manu Magda, 2009c)
} 
Felecan, N. (1994). Elemente arhaice latine în graiurile din nordul țării, în „Buletinul științific, seria A, Filologia”, vol. IX, p. 3743.

Frâncu, C. (2009). Gramatica limbii române vechi (1521-1780), Casa Editorială Demiurg, Iași.

GALR = Guțu Romalo, V. (coord.) (2008). Gramatica limbii romane. I. Cuvântul. II. Enunțul, tiraj nou, revizuit, București, Editura Academiei Române.

GBLR = Pană Dindelegan, G. (coord.) (2010). Gramatica de bază a limbii romane, Editura Univers Enciclopedic, București.

Gonçalves, M. (2000). Sur le statut linguistique de l'interjection, în „Actas del VIII congreso de Lingüística General”, Universidad Autónoma de Madrid, p. 14, [online].

Gonçalves, Miguel (2002). A Interjeição em Português. Contributo para uma Abordagem em Semântica Discursiva, FCT/FCG, Lisboa.

Hopper, P.J. \& Traugott, E. C. (1993). Grammaticalization, ed. I-a, Cambridge University Press, Cambridge (ed. a II-a: 2003).

Manu Magda, M. (2008). Limba română vorbită, în GALR, II, p. 869-904.

Manu Magda, M. (2009a). Indici de alocutivitate în limba română actuală (clasa alocutivelor interjecționale), în Pană Dindelegan, 2009, p. 459-491.

Manu Magda, M. (2009b). Prezentativele în textele dialectale româneşti, în „Lucrările celui de-al XIII-lea Simpozion Internaţional de Dialectologie”, vol. I, Bala Mare, 19-21 sept. 2009, Editura Mega, Cluj-Napoca, p. 189-205.

Manu Magda, M. (2009c). Un alocutiv pragmatizat în limba română, în „Limba română”, vol. LVIII, nr. 2, p. 230-237.

Manu Magda, M. (2014). Vorbirea directă în texte românești din secolul al XVI-lea, în Zafiu, R. et al. (eds), Limba română: diacronie și sincronie în studiul limbii române, I, Editura Universității din București, București, p. 287-296.

Manu Magda, M. (2017). Gramaticășipragmatică. Un studiu de caz: interjecția Doamne! în limba română, în Dragomirescu, A. et al. (eds), Sintaxa ca mod de a fi. Omagiu doamnei profesoare Gabriela Pană Dindelegan, la aniversare, Editura Universității din București, București, p. 265-276.

Olivier, C. (1985). L'art et la manière : comment dans les stratégies discursives, în „Langages”, vol. 20, nr. 80, déc. 1985, p. 71-98, Crossref.

Olivier, C. (2000). L'interjection mon Dieu : variabilité sémantique et situations de discours, în „Cahiers de praxématique”, nr. 34, p. 161-189, [online].

Pană Dindelegan, G. (ed.) (2009). Dinamica limbii române actuale, Editura Academiei Române, București.

sOR = Pană Dindelegan, G. (ed.) (2016). The Syntax of Old Romanian, Oxford University Press, Oxford; Anexe online.

Ștefănescu, A. (2007). Conectori pragmatici, Editura Universității din București, București.

TDRG = Tiktin, H. (2004). Rumänisch-Deutsches Wörterbuch, Harrassowitz Verlag, Wiesbaden.

Traugott, E. C. (1989). On the rise of epistemic meanings in English: An example of subjectification in semantic change, în „Language", vol. 65, nr. 1, p. 31-55, Crossref.

Traugott, E. C. (1995). Subjectification and Grammaticalization, în Stein, D. \& Wright, S. (eds), Subjectivity and Subjectivization in Language, p. 31-54, Cambridge University Press, Cambridge.

Vişan, R. (2002). Observații asupra sintaxei exclamativelor cu ce, ce de, cît și cum în română, în Pană Dindelegan, G. (coord.), Perspective actuale în studiul limbii române: actele colocviului Catedrei de Limba Română, 22-23 noiembrie 2001, Editura Universității din București, București, p. 415-425.

Zafiu, R. (2005). Conjuncțiile adversative din limba română: tipologie și niveluri de incidență, în Pană Dindelegan, G. (coord.), Tradiție și inovație in studiul limbii române, Editura Universității din București, București, p. 239-252. 